\title{
NAUKOWE FASCYNACJE SZTUKI. PRZEGLĄD ARBITRALNY
}

Paweł Możdżyński

Uniwersytet Warszawski

\section{/// Fascynacja nauką}

W wielu miejscach współczesnego pola sztuk plastycznych widać niezwykłą fascynację artystów nauką. Jest to - w pewnym sensie - kontynuacja: dawni mistrzowie też inspirowali się odkryciami naukowymi, nieraz sami stając się ich autorami. Mimo nowoczesnej specjalizacji, wyraźnie odgraniczającej pole nauki od pola artystycznego, w XX i XXI wieku wiele dzieł i tekstów teoretycznych, a nawet całych kierunków w sztuce powstawało pod wpływem rozlicznych inspiracji naukowych. W poniższym tekście mam zamiar zastanowić się nad najważniejszymi aspektami owej fascynacji nauką artystów XX i XXI wieku. Ograniczę się do omówienia wpływu nauki na pole sztuk plastycznych (wizualnych) (zob. Bourdieu 2001: 260-261, 441, 444; 2005: 11). Nie będę więc tu pisał o innych sztukach kształtujących autonomiczne pola (muzyka, teatr, film, literatura), mając oczywiście świadomość względności wytyczonych granic - zwłaszcza w dziedzinie nowych mediów (np. performans, sztuka wideo). Nie poruszę też kwestii dzieł plastycznych tworzonych poza autonomicznym polem sztuki - a więc na przykład sztuki amatorów, sztuki religijnej. W tym krótkim szkicu oczywiście nie uda mi się wspomnieć o wszystkich interesujących artystach - zbadam twórczość najważniejszych malarzy, rzeźbiarzy i performerów, poddam eksploracji te dzieła i wypowiedzi teoretyczne, w których odbijają się najmocniej podstawowe kierunki zainteresowania nauką w sztukach plastycznych XX i XXI wieku. Będę sporo cytował samych artystów, by udostępnić czytelnikowi „smak” dyskursu sztuk wizualnych, tak by moje konstrukcje teoretyczne nie przysłoniły najważniejszych aspektów rzeczywistości badanej. Zacznę swoje rozważania od artystycznych inspiracji matematyką i fizyka. 


\section{/// Matematyka, (meta)fizyka, sztuka}

W XX i XXI wieku wielu artystów fascynowało się i nadal fascynuje matematyką. Można podać wiele przykładów potwierdzających tę tezę. Wassily Kandinsky, jeden z ojców abstrakcjonizmu, napisał: „Ostatecznym abstrakcyjnym wyrazem w każdej sztuce jest liczba" (Kandinsky 1996: 121). Georges Vantongerloo malował abstrakcyjne obrazy na podstawie obliczeń matematycznych - co uwidaczniało się nawet w tytułach jego prac, np.: Kompozycja XV wynikajaca z równania $y=x^{2}-b x+18$. Vantongerloo prorokowal: „Niedaleki jest czas, gdy sztuka i nauka utworza jednorodną całość" ([w:] Osińska 2005: 190-191). Polski klasyk abstrakcjonista, działający w pierwszej połowie XX wieku, Władysław Strzemiński, poszukiwał ,jednolitego wyrazu liczbowego całego obrazu” (Strzemiński 1975: 47 za: Brogowski 2001: 27). Z kolei jeden z jego następców, Ryszard Winiarski, już w latach sześćdziesiątych (sic!) XX wieku konstruował swoje obrazy wypełnione „pikselami” na podstawie wyliczeń matematycznych (seria Próba wizualnej reprezentacji rozkładów statystycznych), a w pracy magisterskiej bronionej na Akademii Sztuk Pięknych przedstawił koncepcję „programowania obrazów”. W latach osiemdziesiątych próby integracji sztuki i nauki zaczął łączyć z intuicją i poszukiwaniami duchowymi. Cykl swych instalacji Winiarski zatytułowal Geometria czyli szansa medytacji (Gorządek 2006).

Łączenie sztuki, nauki - w tym matematyki - z duchowością jest w XX i XXI wieku powszechne. Geometria w sztuce - według współczesnego malarza Kojiego Kamojiego - to „wyraz ducha” (Kowalska 2001b: 100). Oczywiście pomaga tu artystom wiedza o wspólnych korzeniach i powiązaniach z religijnymi kultami, na przykład pitagorejczyków, jak też pojawiające się w różnych kulturach przypisania mistycznej wartości liczbom (Kowalska 2001a: 11) - co jest, jak sądzę - wyrazem powrotu do przednowoczesnego początku jedności mistyki, nauki i sztuki. Pasuja w tym miejscu słowa Marcela Briona, klasyka sztuki XX wieku, wyjaśniające częściowo ten fenomen:

„Z pomocą wiedzy [...] o «Świętych liczbach» i «złotych proporcjach» próbuje artysta czynnik boski czy święty ład świata przedstawiać w formach, które odpowiadaja tym liczbom i wszechmocnym proporcjom. Ta czysto geometryczna-arytmetyczna sztuka jest zrozumiała tylko dla nielicznych wtajemniczonych”. (Brion 1960: 31, za: Kowalska 2001a: 19)

Najbliżej tego geometrycznego „świętego ładu świata” dotarli w XX wieku - jak sądzę - właśnie abstrakcjoniści. Dla nich geometria jest swoistym magicznym, mistycznym „alfabetem” - co dobitnie sformułowała 
polska artystka, Wanda Gołkowska ([w:] Kowalska 2001b: 64), jest „nośnikiem energii" - to określenie Teresy Bujnowskiej ([w:] Kowalska 2001b: 34). Figury geometryczne są z kolei - dla Tadeusza Wiktora - ,archetypami”: medytacja nad nimi pozwoli dotrzeć „do samego jądra Rzeczywistości” (Kowalska 2001b: 162).

Ciekawie łączy matematykę ze sztuką Janusz Kapusta. Ten artysta-odkrywca zajmował się opisaniem wszystkich aspektów punktu, próbował odpowiedzieć sobie na fundamentalne pytanie: ,jak [...] narysować nieskończoność? To pytanie doprowadziło go do odkrycia w 1985 roku nowego, dotychczas nieznanego geometrycznego kształtu - jedenastościennej bryły, której nadał nazwę „K-dron” ${ }^{1}$ (Kowalska 1999b: 9-10). Odkrycie K-dronu ma wiele implikacji i owocuje różnymi zastosowaniami. Bryły sa wystawianymi w galeriach dziełami sztuki. Powierzchnia K-dronu jest jak twierdzi artysta - „czasoprzestrzennym modelem równania drgającej struny. Dzięki K-dronowi ujawniło się nowe, nieznane wcześniej połączenie między drgającą struną a symetriami sześcianu" (Kowalska 2001b: 105). K-dron okazał się też wynalazkiem w dziedzinie materiałoznawstwa i ma swe zastosowanie na przykład w budownictwie (Kowalska 1999b: 12). Co ciekawe, Janusz Kapusta nie porzucił mimo tych praktycznych wymiarów swych odkryć - poszukiwań „sensu”, cały czas pragnie dotrzeć do tego, „co wewnątrz” i ,na zewnątrz” (Kapusta, [w:] Kowalska 2001b: 105).

$\mathrm{Na}$ zakończenie rozważań o fascynacji matematyką przytoczę słowa jednego z najważniejszych artystów drugiej połowy XX wieku, Josepha Beuysa: „Można mianowicie jak najbardziej artystycznie poczynać sobie w matematyce, matematyka bowiem operuje formami”" (Beuys 1987: 269). Dla Beuysa „każdy jest artystą", a sztuką była każda twórczość, także nauka, także matematyka.

Pora zastanowić się nad fascynacjami fizyką, która być może najbardziej ze wszystkich nauk fascynuje twórców współczesnych. Artyści, ze względu na wizualny charakter ich twórczości, w sposób oczywisty są zainteresowani odkryciami z dziedziny optyki. Jak wiadomo, gdyby nie wiedza z tej dziedziny, nie powstałby w XIX wieku impresjonizm. Na początku XX wieku awangardziści kontynuowali fascynacje optyka, co bardzo dobrze pokazuje fragment manifestu Malarstwo futurystyczne:

„Wszystko się rusza, wszystko biegnie, wszystko się obraca gwałtownie. Żaden kształt nie trwa przed nami ustalony, lecz ukazuje się i znika bezustannie. Wskutek tego, że siatkówka zatrzymuje obraz, wszystkie rzeczy

\footnotetext{
${ }^{1}$ Słowo „hedron” jest używane w języku angielskim do określania ścian w wielościanach, „,k” jest jedenastą litera w alfabecie angielskim.
} 
w ruchu mnożą się, odkształcają i w przestrzeni, którą przebiegają, tworzą ciagi wibracji”". (Boccioni 1977: 275)

Do dziś optyka jest dziedziną szczególnie frapującą dla artystów, co jakiś czas szczególnie mocno daje o sobie znać, kształtując całe kierunki - jak to było wyraźnie widoczne w wypadku rozwijającego się w latach pięćdziesiątych i sześćdziesiątych op-artu (optical art).

Artystów XX i XXI wieku wyraźnie fascynuje „,nowa fizyka” (fizyka relatywistyczna) - teorie stworzone przez Bohra, Einsteina, Heisenberga. $\mathrm{Na}$ przykład abstrakcja niegeometryczna - jak sądzą Adam Kotula i Piotr Krakowski - ma swoje źródło w relatywizującej dotychczasową scjentystyczna perspektywę zasadzie nieoznaczoności Wernera Heisenberga (Kotula, Krakowski 1973: 182). Echa „nowej fizyki” wprowadzającej - mówiąc językiem Kuhna (2009) - „, nowy paradygmat” słychać w wielu tekstach programowych sztuki XX wieku. Co ciekawe, w wypowiedziach awangardzistów $\mathrm{z}$ początku $\mathrm{XX}$ wieku nauka była wiązana $\mathrm{z}$ tym, co „archaiczne" i ,pierwotne”. Jak wytłumaczyć tę logiczną sprzeczność, polegająca na połączeniu archaiczności, opartej na irracjonalności, i nauki, będącej esencją racjonalności? Otóż - jak sądzę - awangardzistom chodziło o przekroczenie granic narzuconych przez ład wczesnonowoczesny. Nauka, jak przyznali futuryści, „sprowadziła ludzi do swego rodzaju barbarzyństwa, do cudownego wyższego barbarzyństwa"; odkryła przed ludźmi nowy świat, w którym stare zasady i idee kulturowe już nie obowiązuja, świat, w którym każda zasada, reguła, konwencja są unieważnione, poddane watpieniu ugruntowanemu na relatywizmie nowej, całościowejbo przekraczającej klasyczne reguły i podziały - nauki. Sztuka nieoddzielona od nauki i zarazem ezoteryki ma ujmować świat w jego całości. „Posiadamy nowy instynkt - instynkt kompleksowości. Ujmujemy wszystko - mówił w 1914 roku Boccioni - w powiązaniu ze skomplikowana całością" (Boccioni 1914: 38 i n., za: Baumgarth 1988: 231). Tak więc ważne, zapożyczane z dyskursu fizyki elementy są splatane z dyskursem okultystycznym. Na przykład Gino Severini mówił o „czwartym wymiarze”: „to nic innego, jak IDENTYFIKACJA PRZEDMIOTU I PODMIOTU, CZASU I PRZESTRZENI, MATERII I ENERGII. Paralelności «kontinuum fizycznego», które dla geometry są tylko hipotezą, urzeczywistniaja się w cudzie sztuki”" (Severini 1977: 176). Także Victor Vasarely, przedstawiciel op-artu, posługiwał się terminami charakterystycznymi dla fizyki (przestrzeń, pole, fale, cząsteczki). „Moja sztuka - pisał - znów transponuje naturę, tym razem naturę fizyki czystej, w ten sposób, że pozwala psychicznie pojąć świat" (Vasarely 1970: 73, za: Kotula, Krakowski 1973: 183). 
Pojawiają się też próby połączenia nauki z tzw. parapsychologią, radiestezją czy też alchemią (np. w pracach Natalii LL, Jerzego Rosołowicza, Jarosława Kozakiewicza).

Podsumowując tę cześć wywodu, przywołam jeszcze koncepcję Umberto Eco, który za Georges'em Mathieu pokazal powiązania pomiędzy różnymi teoriami naukowymi a zjawiskami artystycznymi. Powiązał nowe geometrie nieeuklidesowe $\mathrm{z}$ fowizmem i kubizmem; pojawienie się liczb urojonych i pozaskończonych oraz teorii zbiorów z malarstwem abstrakcyjnym; próby aksjomatyzacji geometrii Hilberta z neoplastycyzmem i konstruktywizmem; teorię gier z action painting (Eco 2008: 197). Warto jeszcze wspomnieć, że Kuhn w swej teorii rewolucji naukowych (Kuhn 2009) pokazuje, że odkrycia fizyczne XX wieku przełamały stary paradygmat - sposób widzenia świata oparty między innymi na obiektywistycznej teorii Newtona. Tak więc „nowa fizyka” ukształtowała nowe postrzeganie świata przez artystów. Tezy Eco współbrzmia z koncepcją Kuhna: Eco zauważył, że fizyka wprowadziła w obszar światopoglądowy takie oto pojęcia: przypadek, nieokreśloność, wieloznaczność, prawdopodobieństwo. Zreszta, jak stwierdził, „otwarcie oraz dynamizm dzieła” - centralne kategorie Drieła otwartego - „przywodzą na myśl pojęcia nieokreśloności i nieciagłości, właściwe fizyce kwantowej, równocześnie stanowią ilustracje pewnych sytuacji w fizyce Einsteinowskiej” (Eco 2008: 93).

\section{/// Sztuka biologiczna: bioart}

Marc Quinn w 2001 roku do londyńskiej National Portrait Gallery wstawił Genomony portret sir Johna Sulstona - biologa molekularnego, noblisty. Ten abstrakcyjny obraz został stworzony przez wyhodowane kolonie przezroczystych bakterii z fragmentami DNA pobranego z nasienia portretowanego naukowca (Bakke 2008). Eduardo Kac w 2000 roku doprowadził do narodzenia się „GFP Bunny” - królika nazwanego Alba $z$ wszczepionym naturalnym genem fluorescencji wypreparowanym z meduzy, przez co zwierzak po naświetleniu świecił w ciemności. W ramach przedsięwzięcia „Eighth Day” Kac pokazał w latach dziewięćdziesiątych żywe transgeniczne istoty - między innymi rośliny, meduzy, ryby i myszy. Organizmy te miały zmieniony kod DNA, były fluorescencyjne, tworzyły własny ekosystem (Jurgielewicz 1996). Kac wykreował też nową formę życia, którą nazwał „Edunia”. Wystawił ją na Biennale Sztuki Meditations w Poznaniu. To kwiat - hybryda genetyczna - stworzony z petunii i krwi artysty. „Bladoróżowe płatki kwiatu poprzecinane są czerwonymi żyłkami, których każda komórka cechuje się ekspresja genu artysty. [...] Efektem 
tej molekularnej manipulacji jest kwiat tworzący żywy obraz ludzkiej krwi pulsującej w żyłach rośliny" (Kac 2010). Warto odnotować, że na sympozjum „Life Science” w 1999 roku (festiwal Ars Electronica w Austrii) Kac powołał nowy nurt - sztukę transgeniczna, która ma polegać na tworzeniu nowych form życia ze zmutowanym kodem genetycznym. Jak sam podkreśla, w jego intencji nie leży jeszcze większe uprzedmiotowianie przyrody, ale jest zainteresowany tworzeniem ,nowych społecznych podmiotów" (Bakke 2008; Jurgielewicz 2006). Kac próbuje stworzyć swoista nową przestrzeń artystyczną (i życiową?) opartą na współdziałaniu organizmów żywych i komputerów. W pracy Genesis powiązał ze sobą podstawy kultury europejskiej z procesami życiowymi: fragment Biblii - księgi źródłowej dla cywilizacji europejskiej - zapisał w pierwszym, według artysty, kodzie komunikacyjnym epoki globalnej: alfabecie Morse'a. Tak zmieniony zapis Biblii przekonwertował na łańcuchy DNA i wprowadził do genomu bakterii. Bakteria w powiększonej formie stała się obiektem projekcji wideo w galerii i w internecie. Warto, jak sądzę, przytoczyć dłuższy opis tej zadziwiającej pracy:

„Instalacja składała się z probówki z bakteriami, przenośnej kamery mikrowideo, lampy UV i mikroskopu, podłączonych do projektora, oraz dwóch komputerów pracujących bezpośrednio w sieci. Jeden z nich służył jako serwer pilotujacy napływające dyspozycje odnośnie do aktywacji promieniowania UV, drugi zaś był odpowiedzialny za syntezę muzyki DNA. Projekcja wideo prezentowała interakcje i podziały bakterii. Internauci wpływali bezpośrednio na proces poprzez włączanie i regulację natężenia oświetlenia UV. Fluorescencyjna proteina w bakteriach reagowała na promieniowanie poprzez emisję widocznego światła. Wpływ natężenia UV polegał na niszczeniu sekwencji DNA w plazmidach. Na prawej i lewej ścianie wyeksponowano wielkoformatowe teksty: sentencję z Księgi Rodzaju oraz graficzny zapis genu Genesis". (Jurgielewicz 2006)

Warto podkreślić specyficzne znaczenie tytułów dwóch przedsięwzięć Kaca: Ósmy dzień i Genesis - autor sygnalizuje, że świadomie przywłaszcza sobie kompetencje kreatora, niegdyś przyznawane Bogu, a od romantyzmu do dziś stanowiące część wyposażenia artysty funkcjonującego w nowoczesnym polu artystycznym ${ }^{2}$.

Innym artystą posługującym się w swej twórczości metodami zaczerpniętymi z biologii jest Zbigniew Oksiuta. Polski artysta, jak się wydaje,

\footnotetext{
${ }^{2}$ Pojawiły się zarzuty, że Kac dokonał falsyfikacji, a organizmy, które pokazał, nie zostały poddane mutacji genetycznej. Sprawa do dziś nie została jednoznacznie wyjaśniona, a - moim zdaniem - cała dyskusja staje się częścią projektu tego artysty. Postawić można bowiem pytanie: czy Kac sobie zakpił z poszukiwań naukowych na polu sztuki?
} 
mniej ingeruje w procesy życiowe organizmów, które „wystawia”, niż Kac. Jak pisze Oksiuta, celem prowadzonych przez niego „badań” jest „kształtowanie form i obiektów biologicznych jako nowych habitatów" (Oksiuta 2007: 46). Na wystawie w Centrum Sztuki Współczesnej w Warszawie w 2007 roku pokazal formy ,wykonane z polimerów biologicznych pochodzenia zwierzęcego i roślinnego, jak żelatyna, agar, agaroza, skrobia [...] Wyjściowym kształtem obiektów były proste bryły i figury: kula, prostopadłościan, walec, pryzma, a założeniem badań była obserwacja procesów deformacji bez interwencji estetycznych i formalnych". W katalogu podkreślił: „Chaotyczne krzywizny i fraktalne zniekształcenia są efektem precyzyjnych procesów biologicznej samoorganizacji i stanowią fizyczne i chemiczne reguły porządku i piękna w świecie ożywionym" (Oksiuta 2007: 36). Na tej wystawie przedstawił też „polimery biologiczne”, czyli „układy skondensowane utworzone $\mathrm{z}$ makrocząsteczek łańcuchowych pochodzenia naturalnego". Warto zauważyć specyficzność tytułów wystawionych prac, na przykład Forma 1921202b, 2002. Tytuły zostały opatrzone adnotacjami.: „Materiał: żelatyna $270^{\circ}$ Bloom, kolor: karmina, E 120, 50 x 40 x 30 cm" (tamże: 38). Dzieła, które można było oglądać w CSW i przedstawione w katalogu, mają różną formę: są to organizmy o regularnych i nieregularnych kształtach, maja rozmaite kolory, sa przezroczyste i nie, matowe i błyszczące, różnią się też rozmiarami - od kilku centymetrów do kilku metrów. Dzieła te przypominają z wyglądu - a właściwie nimi są abstrakcyjne rzeźby.

W ramach swoich eksperymentów Oksiuta współpracował - jak zaświadczał - z różnymi instytucjami badawczymi (Instytut Hodowli Roślin Maxa Plancka w Kolonii, Instytut Fizjologii Molekularnej i Biotechnologii Roślin IMBIO uniwersytetu w Bonn, Instytut Botaniki i Instytut Chemii Fizycznej uniwersytetu w Kolonii, Instytut Biologii w Białymstoku, Niemiecka Agencja Kosmiczna; Europejska Agencja Kosmiczna). Wystawiał na Biennale Architektury w Wenecji, Biennale Sztuki Elektronicznej w Perth (Australia), Ars Electronica w Linzu, wykładał gościnnie na uniwersytetach, w Niemieckiej Agencji Kosmicznej, szkołach artystycznych (tamże: 79). Na festiwalu Ars Electronica w Linzu w 2007 roku Oksiuta został nagrodzony w nowo stworzonej dziedzinie sztuk hybrydycznych.

Ciekawe z punktu tematyki mego tekstu są też komentarze artysty przedstawione w katalogu wystawy. Jego badania - jak pisze - sa „próba analizy niestabilnych, płynnych zjawisk w celu wypracowania warunków, które mogłyby dać początek autonomicznym procesom samoorganizacji i umożliwić powstanie nowych form biologicznych" (Oksiuta 2007: 6). 
Według Oksiuty tylko organizmy żywe są w stanie przeciwstawić się zachodzącej entropii (stanowi nieuporządkowania), gdyż przez „pomnażanie własnej informacji wewnętrznej [...] porządkują się i zmniejszają entropię" (Oksiuta 2007: 4). W wizji artysty przeciwnikiem Gai (Matki-Ziemi postrzeganej jako żywy organizm) jest „człowiek, inteligencja, kultura” - ludzkość „nie przestrzega kosmicznych reguł gry: doboru naturalnego, samoregulacji, i cyklicznej ekonomii". W tym, co mówi artysta, wyraźnie słychać ekologiczny punkt widzenia: „niepohamowany wzrost i zachłanność użytkowników planety dawno przekroczyły granicę jej wytrzymałości” (Oksiuta 2007: 18). Swe badania Oksiuta widzi jako możliwość uratowania planety. Przyszłością życia ma się stać zasiedlenie kosmosu przez żywe organizmy: „Nie supertechnologie, nie komputery, nie kosmonauci, ale mikroskopijne łańcuchy DNA z milionami lat ewolucyjnych doświadczeń umożliwia powstanie nowych cywilizacji w kosmosie". W jego wizji statkiem kosmicznym przyszłości jest komórka, bowiem jest wyposażona ,we wszelkie dane i [...] niezbędne parametry, aby samodzielnie podjąc wyzwanie poznania nowego świata" (Oksiuta 2007: 28).

Powyżej omówione artystyczne przedsięwzięcia - korzystające z metod zaczerpniętych z biologii i biotechnologii - mieszczą się w szerokim, wewnętrznie zróżnicowanym i trudnym przez to do zdefiniowania kierunku sztuki, któremu nadano nazwę „bioart”. Dzieła wchodzące w jego zakres w różny sposób są związane z procesami życiowymi, a artyści tego nurtu zapożyczają wiedzę i metody od biologii i technologii genetycznej. Bioart początkowo był związany wyłącznie z biotechnologiami - co uwidaczniała początkowa nazwa (genetic art), później zainteresowania bioartystów rozszerzyły się na inne obszary, m.in. kultury tkankowe i komórkowe, neuropsychologię, biorobotykę, ludzkie przeszczepy. Dziś w zakres bioartu wchodzą tzw. „mokre media”, które Monika Bakke definiuje jako „bezpośrednie angażowanie przez artystów rozmaitych form życia i biotechnologii" (Bakke 2008).

Przyglądając się dokonaniom twórców bioartu, nie sposób nie odnieść wrażenia, że kontynuuja oni tradycję rozpoczętą w XIX wieku, polegająca na utożsamieniu roli artysty z kompetencjami kreatora. Dziś artysta już nie ma odwzorowywać tego, co jest, jego dzieła nie mają przedstawiać, twórca XXI wieku w pełnym słowa tego znaczeniu ma tworzyć nowe formy życia. Widać, jak artysta, nieograniczony metodologia czy nawet kodeksem etycznym instytucjonalnej nauki, kierowany swoją wyobraźnia, miesza to, co artystyczne, z tym, co naukowe, korzystając przy tym z najnowszych odkryć biologii i biotechnologii. Zauważalne jest też korzystanie $z$ autorytetu 
nauki - artyści chwalą się wspólpracą z instytucjami naukowymi, tytuły ich prac i nazwy festiwali odnoszą się do kategorii wypracowanych przez biologię. Do tego wszystkiego został jeszcze dołączony mistycyzujący przekaz: Ziemia jako Gaja, powrót do początku, zjednoczenie z wszechświatem. Widać wyraźnie, że biologia i biotechnologie są swobodnie łączone w tym zadziwiającym kolażu - zwanym bioartem - z artystyczną ideologią i koncepcjami mistycznymi.

\section{/// Artystyczna psychologia}

Zainteresowanie sferą ludzkich emocji i - szerzej - psychiki to dla artystów nic nowego, każde bowiem dzieło sztuki jest zarówno owocem emocji artysty, jak też czynnikiem wpływającym na emocje odbiorcy, na przykład wywołującym katharsis. Jednak w sztuce XX i XXI wieku fascynacja ludzka psyche przybrała niespotykane - jak sądzę - rozmiary i kształty. Sztuki plastyczne stały się polem badania ludzkich emocji, do czego posłużyła cały czas rozwijana swoista psychologia artystyczna - dyscyplina sztuki współczesnej wykorzystująca elementy dyskursu i niektóre narzędzia psychologii naukowej i psychoterapii w celu eksploracji i transformacji ludzkiego ,ja”. Początki tworzenia psychologii artystycznej widać już w drugiej dekadzie XX wieku - dadaiści zainteresowali się „przypadkiem” jako wyrazem opisywanej przez Freuda „nieświadomości”. Przypadek (zwany też „przypadkiem obiektywnym”) miał być według nich ingerencja „tego, co prawdziwe”, tego, co niezakłamane przez świadomość zbiorowa i rządzące nia konwencje, miał być wyrazem prawdy obiektywnej. Powstały oparte na przypadku nowe media artystyczne: dekalkomania, frotaż, kolaż (później nawet kierunki: taszyzm, action painting czy happening) (Richter 1983: 92, 93-94). Surrealiści z kolei zafascynowali się badanymi przez psychologów i psychiatrów stanami odmiennej świadomości - histeria, „stanami maniakalnymi” czy fenomenem hipnozy. Powołali Biuro Badań Surrealistycznych, skupiające uwagę na eksplorowaniu stanów zmienionej świadomości. Salvador Dali - jeden z najbardziej sławnych nadrealistów - wymyślił nawet „metodę paranoiczno-krytyczną” (Janicka 1969: 243, przyp. 67).

W drugiej połowie XX wieku zainteresowania sfera psychologii w polu sztuki nie wygasły. Wielu artystów w swojej twórczości eksploruje ludzkie emocje, wśród nich jest jeden z najważniejszych artystów wideo - Bill Viola (notabene absolwent studiów psychologicznych). Bardzo dobrze jego badawcze nastawienie ukazuje wideoperformans Kwintet zdumionych, 
w którym performerzy głęboko wchodzą w różne stany emocjonalne, a wraz z nimi - widz. Przytoczę tu fragment autorskiego opisu wideo Billa Violi:

„Obserwujemy grupę pięciorga ludzi (jedna kobieta i czterech mężczyzn), stojących blisko siebie, ogarniętych falą silnych uczuć, która wydaje się ich przytłaczać. Gdy sekwencja się rozpoczyna, wyraz twarzy poszczególnych postaci zaczyna się zmieniać, w miarę jak emocje, u każdego inne, narastaja i osiagają szczytowe natężenie. Po kilku minutach słabna, a u każdej postaci widoczne są oznaki wyczerpania. [...] Krańcowo zwolnione tempo uwidacznia najdrobniejsze detale i subtelne niuanse wyrazów twarzy, tworząc subiektywną psychologiczna przestrzeń, w której czas zostaje zawieszony zarówno dla aktorów, jak i widzów". (Viola 2007: 33)

Nastawienie na badania ludzkiej psyche w ramach przedsięwzięć artystycznych jest widoczne $u$ wielu innych przedstawicieli pola sztuki, dla których jest charakterystyczne przejęcie kategorii psychologicznych. Twórcy i krytycy mówią na przykład o samorealizacji przynoszonej przez sztukę (Puchała 2007: 46). Nie zatrzymują się na „badaniu”, celem sztuki staje się „diagnozowanie kompleksów” i „ujawnianie treści wypartych”. „Sztuka jest terapią" - mówił wprost Joseph Beuys - bowiem wskazuje „urazy swych czasów", umożliwia wypowiedzenie tego, co zostało wyparte do nieświadomości, a „wszystko musi zostać wyrażone” (Beuys 1987: 269; 1990: 19-20). Swe koncepcje na temat psychoterapeutycznej natury sztuki wprowadzał w czyn przez swoje akcje. W jednej z nich („Lubię Amerykę i Ameryka lubi mnie") zamknął się w klatce z Kojotem symbolizującym - według artysty - rdzenną ludność Ameryki po to, by nawiązać „dialog energetyczny” ukierunkowany na uzdrowienie społeczeństwa amerykańskiego (por. Fisher-Lichte 2008: 170).

Terapeutyzować społeczeństwo chcieli także - znani ze swego okrucieństwa - akcjoniści wiedeńscy: ich brutalne akcje miały wybudzić społeczeństwo austriackie i pozwolić zetknąć się z wypartą przeszłością - zaangażowaniem w faszyzm. Zresztą Herman Nitsh do dziś prowadzi w swym zamku krwawe rytuały, podczas których można tarzać się w mięsie zabijanych przez siebie zwierzą - w ten sposób, jak twierdzi artysta, człowiek kanalizuje swoje pierwotne, zepchnięte do nieświadomości instynkty, dzięki czemu nie musi ich realizować przez wywoływanie wojen (Zydorowicz 2005: 74).

Fascynację psychologia wykazują też polscy artyści, wśród których wybijaja się twórcy polskiej sztuki krytycznej, powstałej w latach 90. Jednym z celów tego prądu jest ujawnienie tego, co ukryte, obłożone sfera 
tabu w społeczeństwie polskim. Na przykład Katarzyna Kozyra zwracała uwage na wyparty problem zabijania zwierząt (Piramida zwierzat), ludzkiej choroby i śmierci (Olimpia). Problem niepełnosprawności i odcięcia od cielesności podjęli na tym gruncie w swoich przedsięwzięciach między innymi Katarzyna Kozyra (Więy krmi) i Artur Żmijewski (Oko za oko). Żmijewski w swej pracy Berek z 1999 roku dotknął wciąż bolesnej traumy obozów śmierci. Jego wideo pokazuje nagich ludzi bawiących się w berka w komorze krematoryjnej. W tej pracy - jak przyznał artysta - chodziło o to, by „naruszyć mechanizmy wyparcia - ceremoniał składania wieńców, konwencjonalnych przemówień i zapalania zniczy, by otworzyć pamięć zamkniętą na przeżycie. Działaniem, które miało naruszyć tabu, była zabawa i - zdaniem Żmijewskiego - jego akcja przypominała „sytuacje kliniczna w terapii psychologicznej" (Jakubowicz 2004: 15-16).

Z kolei Robert Rumas próbował uzdrowić polską religijność. W pracy „BÓG w mojej OJCZYŹNIE jest HONOROWY” Rumas postawił na półce słoiki z „zamarynowanymi” opłatkami, obrazkami i figurkami Matki Boskiej, biało-czerwoną flaga, monetami i wędlina, w innym jego przedsięwzięciu figura Madonny płakała monetami (Zydorowicz 2005: 173). W komentarzach do swoich prac artysta mówi o „obnażaniu ukrytych za zasłoną sacrum znaczeń” i „przesunięciu kontekstów”, swoją twórczość widzi jako „swego rodzaju quasi-terapię psychoanalityczną” (Rauchenberger, Kölbl 2007).

Krzysztof Wodiczko w ramach prowadzonej przez siebie „pomnikoterapii”, „terapii upamiętniającej” na monumentalnych gmachach, pomnikach i obiektach publicznych (sądach, budynkach rządowych, galeriach, kościołach, pomnikach, mostach itp.) dokonuje projekcji twarzy, cial i ich fragmentów osób wykluczonych, tych, których na co dzień się „nie widzi”: ofiar przemocy (np. ofiary wojen, ofiary przemocy domowej), narkomanów, bezdomnych, biedaków, imigrantów, kobiet, homoseksualistów (Deutsche 2005: 20). Wodiczko konstruuje też różne „urządzenia dezalienacyjne”, których działanie jest ukierunkowane na włączenie do społeczeństwa konkretnych osób. Rozbroja (2000 r.), na przykład, stworzona dla młodych ludzi z trauma - jak twierdził autor - pozwoliła w jednym wypadku uczniowi odrzuconemu przez klasę ze względu na rzekomą inność na nowo zaistnieć w swym środowisku, a w drugim umożliwiła dziewczynie przełamać uraz do mężczyzn przypominających jej ojca (Wodiczko 2005: 97). Wodiczko też otwarcie posługuje się dyskursem psychologicznym - na przykład swe pokazy artysta nazywa „publicznymi seansami psychoanalitycznymi, ujawniającymi to, co kryje nieświadomość budowli” (Wodiczko 1995:115, za: Świtek 2005: 25). 
Co wynika z tego pobieżnego przeglądu prac reprezentujących - jak to ująłem - psychologię artystyczną? Artyści chętnie wchodzą w dyskurs psychologii i psychoterapii. Często w opisie swych dzieł sięgają do kategorii psychologicznych („terapia”, „,samorealizacja”, „mechanizmy wyparcia”, „ujawnianie treści wypartych”, „odreagowanie” itd.), a ich performanse stają się seansami psychoterapeutycznymi. Jednak, tak jak to jest w wypadku fascynacji innymi dyscyplinami naukowymi, artyści dosyć swobodnie sięgaja do teorii i metod badawczych psychologii. Słowem: ideologia i praktyka artystyczna XX i XXI wieku jest przesiąknięta dyskursem psychologicznym. Z punktu widzenia socjologa nie ma w tym nic dziwnego, bowiem psychologia właśnie - jak mówił Bell - zajęła dawna pozycje moralności (Bell 1994: 108), czy - jak to sformułował Giddens - psychoterapia jest instytucjonalnym wyrazem wiecznie zmieniającej się tożsamości człowieka późnonowoczesnego (por. Giddens 2002: 49). Dziś, w późnej nowoczesności, dokonuje się restytucji tego, co było przez wczesnonowoczesną racjonalność stłumione, dziś znów odkrywa się uroki emocjonalności, co wpisuje się - w koncepcji Baumana - w powtórne zaczarowanie świata (Bauman 1996: 46).

\section{/// Artystyczne nauki społeczne}

Awangardziści pierwszych lat XX wieku z wypiekami na twarzy czytali antropologiczne artykuły opowiadające o „dzikich”, „kulturach pierwotnych”, ,sztuce prymitywnej” " ${ }^{3}$. Pod wpływem etnografii została m.in. przeformułowana wizja sztuki: dzieło nie jest już „pięknym przedmiotem” odzwierciedlającym metafizyczną ideę piękna, w podejściu surrealistów reprezentowanym na łamach czasopisma artystycznego „Documents”, współczesne dzieło „,zostaje zrównane z archeologicznym czy etnograficznym artefaktem, stając się usytuowanym poza estetyką antropologicznym dokumentem" (Szerszeń 2007: 244, 245). Antropologiczne fascynacje dadaistów i surrealistów były podporządkowane realizacji celów określonych przez powstałą w romantyzmie ideologię artystyczną. Dla awangardzistów opisywany przez etnografów „dziki” jest lustrem: etnograficzny opis u Leirisa służy odkryciu i zrozumieniu siebie. „Dostrzeżenie inności okazuje się warunkiem koniecznym do tego, by dowiedzieć się, kim jestem" (Kaniowska 2007: 270). Poszukiwanie własnego „ja” w postaci Innego - jak przypuszczam - stało się przyczyną tego, że Picasso zbierał afrykańskie maski, Malewicz zgłębiał kanon staroruskich ikon, Stryjeńska malowała

\footnotetext{
${ }^{3}$ Antropolodzy z kolei też interesowali się sztuką współczesną, o czym świadczy powstanie kierunku zwanego „surrealizmem etnograficznym”.
} 
ludowe wzory. W drugiej połowie XX wieku wielu artystów kontynuowało swe antropologiczne fascynacje, a wśród nich Pollock, Beuys, Nitsch, Kijewski. W latach 70. konceptualista - Joseph Kosuth - definiując „artystę jako antropologa", który bada od wewnątrz własną kulturę za pomoca obserwacji uczestniczącej, nazwał ostateczny wyraz fascynacji artystów antropologia kulturowa (Guzek 2007: 45, Kosuth 1975).

W polu zainteresowań współczesnych artystów znajduje się również socjologia. W 1974 roku został powołany Kolektyw Sztuki Socjologicznej. Sztuka socjologiczna, jak wyjaśnia jeden z jego twórców, narodziła się z socjologii sztuki i jako jedyna ma odniesienia do rzeczywistości społecznej, bowiem jest ufundowana na „praktyce socjologicznej”, „nauczaniu”, ,pracy społeczno-krytycznej”, „ożywieniu i zakłóceniach” (Fisher 1987: 300). Na tej koncepcji odcisnęły swe piętno - jak można się domyślić - teorie Marksa, zarówno w warstwie diagnozy społecznej, jak też ideologii i bazujących na niej prób zmiany rzeczywistości społecznej. Cel socjologii, jakim jest poznanie rzeczywistości społecznej, został w sztuce socjologicznej, wzorem marksizmu, podporządkowany interwencji politycznej socjologia de facto została pomylona z socjotechniką.

Naukami społecznymi niewątpliwie inspiruje się cały krag polskiej sztuki krytycznej. Artur Żmijewski de facto dał temu bezpośredni wyraz, publikując manifest Stosowane Sztuki Spoteczne, w którym sztukę określił jako „dział stosowanych nauk społecznych” ${ }^{4}$, jej celem zaś ma być poznanie społeczeństwa, co - według Żmijewskiego - dzieje się cały czas, bowiem artyści, tak jak socjolodzy i inni naukowcy, „wytwarzają wiedzę”. Z manifestu i innych wypowiedzi Żmijewskiego przebija - jak sądzę pewnego rodzaju frustracja: sztuka nie jest „skuteczna”, gdyż ,jest uparcie redukowana przez ekspertów innych dziedzin do propozycji estetycznej", a wiedza, która wytwarzaja artyści, jest przyjmowana przez społeczeństwo z obojętnością. By to przełamać, sztuka - wnioskuje Żmijewski - powinna wejść w „pole nauki”, a artyści powinni „powrócić do świata”, zaczaçć współpracować z naukowcami - w ten sposób zostanie przywrócona „społeczna skuteczność sztuki”, a w nauce dokona się „decentralizacja, dywersyfikacja źródeł wiedzy” (Żmijewski 2007: 20-21, Cichocki 2008: 10).

Przykładami dzieł wpisujących się w stosowane sztuki społeczne według Żmijewskiego - są przedsięwzięcia Zbigniewa Libery (np. Lóżeczka porodowe dla nastolatek, obóz koncentracyjny z klocków Lego itd.). „To

\footnotetext{
${ }^{4}$ Inspiracją do zatytułowania manifestu (Stosowane Sztuki Społecz̨ne) i wpisania sztuki w zakres stosowanych nauk społecznych stała się dla Żmijewskiego nazwa Instytutu Stosowanych Nauk Społecznych UW, w którym, zreszta, mam zaszczyt pracować.
} 
coś więcej niż obiekty - mówi Żmijewski - to budzące spory fakty społeczne i eksperymenty artysty-antropologa" (Cichocki 2008: 10). Artystyczny eksperyment nie jest możliwy w ramach skonwencjonalizowanego pola instytucjonalnej nauki. Za przykład takiego eksperymentu można podać głośne przedsięwzięcie samego Artura Żmijewskiego - Powtóræ̨enie, w którym autor zrekonstruował słynny - i krytykowany przez środowisko naukowe - eksperyment stanfordski Zimbardo. Żmijewski w swoim eksperymencie doszedł do innych zupełnie wyników niż jego poprzednik. W tym artystycznym performensie biorący udział nie chcieli tak głęboko - jak to miało miejsce u Zimbardo - wejść w narzucone role przez eksperymentatora. Całe przedsięwzięcie zakończyło się ogólną zgodą uczestników (Szotkowska 2005). Akcja Żmijewskiego została skrytykowana międy innymi za niespełnienie kryteriów eksperymentu naukowego. Żmijewski te argumenty nazwał ,imperializmem nauki”, uznał także za wyraz „pogardy” naukowców wobec innych dyscyplin wiedzy, które nie są sformalizowane (Tomaszewski 2008). Z kolei krytycy sztuki będący w polu oddziaływania sztuki krytycznej pozytywnie recenzowali Powtórzenie, które, według nich, kwestionowało naukową „hegemonię w wytwarzaniu wiedzy” i - jak to ujęła Joanna Mytkowska - reprezentowało „alternatywny, równoległy i dopełniający dyskurs poznawczy" (tamże).

Z tych kilku przykładów fascynacji artystów naukami społecznymi jasno wynika, że Hal Foster miał rację, twierdząc, że wiele dzieł sztuki współczesnej jest owocem badań socjologicznych, politologicznych, kulturowych (Foster 1996: 36, za: Guzek 2007: 256-257). Lecz artyści nie zatrzymują się na czerpaniu inspiracji z nauk społecznych, uważają, że sztuka może być (jest) dyscypliną wiedzy, może stać się nauką społeczna, dopełniając skostniała socjologię i „dywersyfikując źródła wiedzy”. Warto jednak zauważyć na przykład w wypowiedziach Żmijewskiego swoisty paradoks: z jednej strony artysta krytykuje naukę za jej "sformalizowanie” i „hegemonię”, ,imperializm”, z drugiej, jest zafascynowany jej „skutecznościa”, powtarza eksperymenty naukowe, inspiruje się nazwami instytutów uniwersyteckich. W przytoczonych wyżej przykładach można odczytać także swobodę (tę, która było widać w fascynacji innymi naukami), z jaką podchodzą artyści do nauki: wybieraja podobające się im fragmenty - i nie zważając np. na standardy obowiązujące naukowców - wlepiaja je w swe dzieła mające strukturę kolażu. Wiedza naukowa jest do tego potraktowana instrumentalnie: chodzi o wykorzystanie jej do zmiany porządku społecznego, socjologia zostaje zredukowana do prostej socjotechniki, podporządkowana projektowi ideologicznemu. Tak więc ideologia 
artystyczna pokazuje artystę w nowym wcieleniu: antropologa-socjologa diagnozującego problemy społeczne i... socjotechnika. A może jest to kontynuacja starej, awangardowej wizji artysty buntownika zmieniającego świat?

\section{///Artystyczna nauka przeżywania}

Sztuka wychodzi poza granice narzucone jej przez klasyczną estetykę. Sztuka jest „narzędziem do poznania” (Kapusta [w:] Kowalska 2001b: 104), jest psychoterapia, stosowaną nauką społeczną. Na jej polu dokonuje się „programowania obrazów” na podstawie rozkładów statystycznych, transponowane są eksperymenty fizyczne, wykonuje się eksperymenty biologiczne i powtarza eksperymenty psychologiczne. Jednak sztuka - co wyraźnie widać dzięki przytoczonym przykładom - nie zamienia się $\mathrm{w}$ naukę, nie poddaje się jej rygorom, nie racjonalizuje się. Elementy dyskursu naukowego splata z innymi opowieściami: zgodnie z późnonowoczesną logiką implozji (por. Ritzer 2001: 225) sklejane są fragmenty wycięte $z$ naukowych książek, traktatów mistycznych i ulotek ideologów. Artyści nie chcą się zamienić w naukowców - pomimo pewnej zazdrości wobec pozycji naukowców i autorytetu nauki - nie zamierzaja się poddać regułom badań naukowych. Pragną zachować wolność przyznaną im w ramach romantycznego mitu artysty. Fragmenty zaczerpnięte z pola nauki budują rewitalizowaną wciąż ideologię artysty, której ważną częścią jest zorientowanie na multiplikowanie doświadczeń.

„Na granicy tego, co w ogóle możliwe - pisał o sztuce końca XX wieku czołowy filozof, Lytoard - wypróbowuje się możliwości odczuwania i wyrażania, poszerzając w ten sposób dziedzinę odczuwanego i odczuwającego, wyrażalnego i wyrażającego. Eksperymentując. [...] Tworzy się przedziwne maszyny, dzięki którym doświadczyć można tego, czego nie sposób było pomyśleć lub odczuć". (Lytoard 1996: 75)

Przemieszanie fragmentów pochodzących z nauki i sztuki służy artystom do sprowokowania jeszcze dziwniejszych, bardziej hybrydycznych doświadczeń (MacCannell 2002; Bauman 2000: 310-313), pozwala im rozwijać artystycz̨na nauke præ̌esyywania - dzięki niej artyści mogą cały czas biec na czele tego wielkiego, wszechogarniającego pościgu za przeżyciami. 
Bibliografia:

/// Bakke M. 2008. Bio art - sztuka in vivo i in vitro. http.//www.obieg.pl/ teksty/4408; dostęp: 10.01.2012.

/// Baudrillard J. 1997. Precesja symulakrów, tłum. T. Komendant, [w:] Postmodernizm. Antologia przektadów pod redakcja Ryszarda Nycza, red. R. Nycz, Wydawnictwo Baran i Suszyński, Kraków, s. 175-189.

// / Baudrillard J. 2001. Ameryka, tłum. R.Lis, Wydawnictwo Sic!, Warszawa.

/// Bauman Z. 1996. Etyka ponowoczesna, tłum. J. Bauman, J. TokarskaBakir, PWN, Warszawa.

/// Bauman Z. 2000. Ponowoczesność jake żródto cierpień, Wydawnictwo SIC!, Warszawa.

/// Baumgarth C. 1988. Futuryzm, tłum. J. Tasarski, Wydawnictwa Artystyczne i Filmowe, Warszawa.

/// Beuys J. 1987. Każdy artysta, [w:] Zmierzch estetyki - rzekomy cæy autentyczny?, t. 2, red. S. Morawski, Czytelnik, Warszawa, s. 268-273.

/// Beuys J. 1990. Teksty, komentarze, mywiady, wyb., oprac. J. Jedliński, tłum. J. Jedliński, A. Sochacki, M. Piotrowska, Akademia Ruchu, Centrum Sztuki Współczesnej, Warszawa.

/// Boccioni U. 1914. Pittura Scultura Futuriste, brak wydawnictwa, Milano,

/// Boccioni U., Carrà C., Russolo, Balla G., Severini G. 1977. Manifest Techniczny, tłum. M. Czerwiński, [w:] Artyśsi o sz̨tuce. Od van Gogha do Picassa, wyb. i oprac. E. Grabska, H. Morawska, PWN, Warszawa, s. 151-154.

/// Bourdieu P. 2005. Dystynkcja. Spoteczna krytyka władzy sadzenia, tłum. P. Biłos, Wydawnictwo Naukowe Scholar, Warszawa.

/// Bourdieu P. 2001. Reguly sz̨tuki. Geneza i struktura pola literackiego, tłum. A. Zawadzki, Wydawnictwo Universitas, Kraków.

/// Brion M. 1960. Geschichte der abstrakten Kunst, Du Mont, Köln.

/// Brogowski L. 2001. Powidoki i po... Unizm i Teoria widzenia W ładysława Strzemińskiego, Wydawnictwo słowo/obraz terytoria, Gdańsk.

// / Cichocki S. 2008. Wstę. Z Arturem Żmijenskim rozmawia Sebastian Cichocki, [w:] Driqqu ciała. Rozmowy z artystami, A. Żmijewski, wyd. II, poprawione i rozszerzone, Wydawnictwo Krytyki Politycznej, Warszawa, s. 7-15. 
/// Clifford J. 2000. Kłopoty z kultura. Dwudziestowieczna etnografia, literatura i sztuka, tłum. E. Dżurak, J. Iracka, E. Klekot, M. Krupa, S. Sikora i M. Sznajderman, Wydawnictwo KR, Warszawa.

/// Eco U. 2008. Dzieto otwarte. Forma i nieokreśloność w poetykach wspótczesnych, tłum. L. Eustachiewicz i in., Wydawnictwo WAB, Warszawa.

/// Eliade M. 1997. W poszukiwanin bistorii $i$ znaczenia religii, tłum. A. Grzybek, Wydawnictwo KR, Warszawa.

/// Fisher-Lichte E. 2008. Estetyka performatywności, tłum. M. Borowski i M. Sugiera, Księgarnia Akademicka, Kraków.

/// Fisher H. 1987. Teoria sz̨tuki socjologicznej, tłum. M. Iwińska, P. Paszkiewicz, [w:] Zmierzch estetyki - rzekomy czy autentyczny?, t. II, red. M. Stefan, Czytelnik, Warszawa, s. 296-303.

/// Foster H. 1996. The Return of the Real. Avant-Garde at the End of the Century, MIT Press, Cambridge.

/// Giddens A. 2002. Nowoczesność i to żsamość. „Ja” i spoteczeñstwo w epoce późnej nowoczesności, tłum. A. Szulżycka, PWN, Warszawa.

/// Gorządek E. 2006. Ryszard Winiarski. http://www.culture.pl/bazasztuki-pelna-tresc/-/eo_event_asset_publisher/eAN5/content/ryszardwiniarski; dostęp: 10.01.2012.

/// Guzek L. 2007. Sz̨tuka instalacji, Zagadnienie zwiazku przestrzeni i obecności w sztuce wspótczesnej, Wydawnictwo Neriton, Warszawa.

/// Jakubowicz R. 2004. Ekstaza pamieci. Z Arturem Żmijewskim rozmawia Rafat Jakubowicz: http://magazynsztuki.eu/old/archiwum/teksty_internet_ arch_all/archiwum_teksty_online_35.htm; dostęp: 02.01.2013.

/// Janicka K. 1969. Światopoglad surrealizmu. Jego zatożenia i konsekwencje dla teorii twórczośsi i teorii sżtuki, PWN, Warszawa.

/// Jurgielewicz M. 2006. Sztuka transgeniczna w twórczości Eduardo Kaca. http.//www.obieg.pl/teksty/5750; dostęp: 12.02.2012.

/// Kac Eduardo 2010. Meditations Biennale 11.09-30.102010.

http.//www.mediations.pl/Kac_Eduardo-226?lid=1\&filtr=all; dostęp: 12.02.2012

/// Kandyński W. 1996. O duchowości w sztuce, tłum. S. Fijałkowski, Państwowa Galeria Sztuki w Lodzi, Łódź. 
/// Kaniowska K. 2007. Leiris i fotografia, „Konteksty”2007, nr 3-4, s. $270-273$.

/// Kosuth J. 1975. The Artist as Anthropologist, The Fox, New York.

/// Kotula A., Krakowski P. 1973. Sztuka abstrakcyjna, Wydawnictwa Artystyczne i Filmowe, Warszawa.

/// Kowalska B. 1999a. Kajetana Sosnowskiego piéc odkryć malarskich, „Format. Pismo Artystyczne"1999, nr 31-32, s. 46-47, 94.

/// Kowalska B. 1999b. Międyy matematyka i sztuka, [w:] K-dron, red. J. Kapusta, Muzeum Sztuki w Łodzi, Galeria Sztuki Współczesnej w Katowice, Łódź -Katowice.

/// Kowalska B. 2001a. Z rozważań nad jezykiem geometrii w sztuce, [w:] W poszukiwwaniu ładu. Artyśsi o sz̨tuce, B. Kowalska, Galeria Sztuki Współczesnej BWA, Katowice.

/// Kowalska B. 2001b. W poszukiwaniu ładu. Artyści o sz̨uce, Galeria Sztuki Współczesnej BWA, Katowice.

/// Kuhn T.S. 2009. Struktura rewolucji nankonych, tłum. H. Ostromęcka, Wydawnictwo Aletheia. Warszawa.

/// Lyotard J.F. 1996. Filozofia i malarstwo w epoce eksperymentu, thum. M.P. Markowski [w:] Postmodernizm. Antologia przektadón pod redakcja Ryszarda Nycza, wyb. R. Nycz, Wydawnictwo Baran i Suszyński, Kraków.

/// MacCannell D. 2002. Turysta. Nowa teoria klasy próżniaczej, tłum. E. Klekot i A. Wieczorkiewicz, MUZA SA, Warszawa.

/// Możdżyński P. 2011. Inicjacje i transgresje. Antystrukturalność sątuki XX $i$ XXI wieku w oczach socjologa, Wydawnictwa Uniwersytetu Warszawskiego, Warszawa.

/// Oksiuta Z. 2007. Formy procesy konsekwencje. Forms, processes, consequences, kat. wyst., Galeria Arsenał, Centrum Sztuki Współczesnej, BiałystokWarszawa.

/// Osińska B. 2005. Sz̨uka i czas. Od klasycyzmu do wspótczesności, wyd. II, Wydawnictwa Szkolne i Pedagogiczne, Warszawa.

/// Puchała M. 2007. Wstep, [w:] Katarzyna Kozyra. In Art Dreams Come True. $W$ sætuce marz̨enia staja się rzeçyymistościa, red. H. Wróblewska, kat. wyst., BWA Wrocław, Wrocław. 
/// Rauchenberger J., Kölbl Al. 2007. „Tak naprawde żadnych Madonn nigdy w mojej twórczości nie byto». Sz̨tuka jako blasfemicz̨na analiza spoteczeństwa. $Z$ Robertem Rumasem rozmawiaja Johannes Rauchenberger $i$ Alois Kölbl. www.obieg.pl/artmix/artmix17_06.php; dostęp: 06.12.2011.

/// Richter H. 1983. Dadaizm. Sztuka i antysztuka, tłum J.St. Buras, Wydawnictwa Artystyczne i Filmowe, Warszawa.

/// Ritzer G. 2001. Magiczny świat konsumpcji, tłum. L. Stawowy, MUZA SA, Warszawa.

/// Severini G. 1977. Mierzenie przestrzeni $i$ czwarty wymiar, tłum. M. Czerwiński, [w:] Artyści o sztuce. Od van Gogha do Picassa, wyb. i oprac. E. Grabska, H. Morawska, PWN, Warszawa.

/// Strzemiński W. 1975. Dualizm i unizm, [w:] tegoż, Pisma, Wydawnictwo PAN, Wrocław.

/// Szerszeń T. 2007. „Documents” 1929-1930, „Konteksty”2007, nr 3-4, s. 240-249.

/// Szotkowska O.K., red. 2005. Artur Żmijewski. Co stało sie raz nie stało sie nigdy, kat. wyst., Zachęta Narodowa Galeria Sztuki, Warszawa.

/// Świtek G. 2005. Architektura + mowa, [w:] Kraysz̨tof Wodiczko. Pomnikoterapia, red. A. Turowski, kat. wyst., Zachęta Narodowa Galeria Sztuki, Warszawa.

/// Tomaszewski Y. 2008. Artyści u psychologów. Artur Żmijewski i Krazysztof Wodiczko w Szkole Wyższej Psychologii Społecznej.

www.obieg.pl/text/08062501.php; dostęp: 14.05.2012.

/// Vasarely V. 1970. Plasti-cité. L'oewvre plastique dans votre vie quotidienne, Casterman, Paris.

/// Viola B. 2007. Kwintet ₹dumionych, tłum. M. Wawrzyńczak, [w:] Bill Viola, red. M. Brewińska, kat. wyst., Zachęta Narodowa Galeria Sztuki, Warszawa.

/// Wodiczko K. 2005. Roz̧broja, [w:] Kraysztof Wodiczkoo. Pomnikoterapia, red. A. Turowski, kat. wyst., Zachęta Narodowa Galeria Sztuki, Warszawa.

/// Żmijewski A. 2007. Polityczne gramatyki obrazón, [w:] Estetyka jako polityka, J. Rancière, tłum. J. Kutyła i P. Mościcki, Wydawnictwo Krytyki Politycznej, Warszawa.

/// Żmijewski A. 2008. Ciało, krawed乏́, brzeg. Z Grzegorzem Klamanem rozmawia Artur Żmijewski, [w:] Dríace ciała. Rozmony z artystami, A. Żmijewski, wyd. II, poprawione i rozszerzone, Wydawnictwo Krytyki Politycznej, Warszawa. 


\section{/// Abstrakt}

Tekst „Naukowe fascynacje sztuki” opisuje zainteresowania współczesnych twórców sztuk plastycznych nauką. Autor po kolei omawia wpływ matematyki, fizyki, biologii, psychologii i nauk społecznych na koncepcje artystyczne, tworzenie trendów, jak też konkretne dzieła sztuki. W tekście pojawia się wiele odniesień do artystów amerykańskich i europejskich, jednak najczęściej występuja przykłady sztuki polskiej (m.in. W. Strzemiński, R. Winiarski, J. Kapusta, Z. Oksiuta, sztuka krytyczna). W podsumowaniu autor analizuje fascynacje artystów nauka, w tym pęd do eksperymentowania w kontekście ponowoczesnej pogoni za przeżyciami.

Słowa kluczowe:

sztuka współczesna, nauka, bioart, ponowoczesność, eksperyment

\section{/// Abstract}

The text of „Scientific fascinations of art” presents contemporary artists' interest in science. The author discusses the impact of mathematics, physics, biology, psychology and social sciences on the artistic concepts, creation of trends, as well as pieces of art. In the text there are some references to American and European artists, but the most common are examples of Polish art (eg W. Strzeminski, R. Winiarski, J. Kapusta, Z. Oksiuta, critical art). In conclusion, the author analyzes scientific fascinations of artists including the rush to experiment in the context of the postmodern quest for experiences.

Keywords:

contemporary visual arts, social science, bio-art, postmodernity 